\title{
Equality of Opportunity and Equality of Outcome
}

ZDENKO KODELJA ${ }^{1}$

$\approx$ The report on the findings of extensive empirical research on equality of educational opportunities carried out in the US on a very large sample of public schools by Coleman and his colleagues has had a major impact on education policy and has given rise to a large amount of research and various interpretations. However, as some interpreters have highlighted, even more important than the findings of the survey themselves has been Coleman's redefinition of equality of opportunity, abandoning the then prevailing conception of equality of educational opportunities as equality of starting points and replacing it with the concept of equality of educational opportunities as equality of educational outcomes. The question is, therefore, whether equality of outcomes really is one of the two types of equality of opportunity. The purpose of the present article is to show that equality of opportunity and equality of outcomes are two different types of equality. If they are different, the interpretation that Coleman has redefined the concept of "equality of educational opportunity" turns out to be incorrect.

Keywords: equality of opportunity, equality of outcome, education, education policy, justice 


\section{Enakost možnosti in enakost rezultatov}

\section{ZDENKo KodelJA}

$\propto$ Poročilo o ugotovitvah obsežne empirične raziskave o enakosti izobraževalnih možnosti, ki jo je v ZDA na zelo velikem vzorcu javnih šol izvedel Coleman s sodelavci, je imelo velik vpliv na šolsko politiko; sprožilo je številne nove raziskave in različne interpretacije. Toda še pomembnejša od samih ugotovitev raziskave je bila - kot poudarjajo nekateri interpreti - Colemanova redefinicija enakosti možnosti, s katero naj bi opustil do takrat prevladujoče pojmovanje enakosti izobraževalnih možnosti kot enakosti izhodišč in ga nadomestil s pojmovanjem enakosti izobraževalnih možnosti kot enakostjo izobraževalnih rezultatov. Vprašanje pa je, ali je enakost rezultatov res ena izmed dveh zvrsti enakosti možnosti. Namen tega članka je pokazati, da sta enakost možnosti in enakost rezultatov dve različni vrsti enakosti. Če sta različni, je razlaga, da je Coleman redefiniral pojem »enakost izobraževalnih možnosti«, napačna.

Ključne besede: enakost možnosti, enakost rezultatov, izobraževanje, šolske politike, pravičnost 


\section{Introduction}

Half a century ago, a famous report on the findings of extensive empirical research on equality of educational opportunities, carried out on a very large sample of public schools by James Coleman and his colleagues on the initiative of the educational authorities in the United States, was published (Coleman et al., 1966). ${ }^{2}$ The results of the study were surprising, as they were contrary to the expectation that the main cause of unequal learning achievements of white and black children resided in the inequalities (financing, equipment, curriculum, etc.) between schools frequented by whites and schools in which blacks were educated. Given the fact that the measurable disparity between these highly racially segregated schools was surprisingly small, it was not possible to explain the large differences in the learning achievements of children using these variables. In addition, it was shown that these differences were already present at the beginning of education, and that they increased by the end of elementary education irrespective of the fact that there was no increase in the difference between the schools that the students attended, ${ }^{3}$ as well as the fact that the differences within individual schools were greater than the differences between schools. ${ }^{4}$ The differences in the educational achievements of the children studied - differences that were identified among both whites and blacks - were attributed in the survey primarily to differences in the material and educational status of their parents. The conclusion therefore followed that the family has a stronger influence on the learning achievements of children than school. This ultimately means that educational inequalities can be neither eliminated nor significantly reduced by levelling the material status of schools or by increasing the investment in schools attended primarily by blacks. 5 These and other research findings, which were valid for the situation at that time and

2 This study is also known as "The Coleman Study" or “The Coleman Report”. However, it remains unclear whether in the cases of naming the report after its principal investigator this is an eponym (as a form of expressing the highest awards for individual achievements in science) or not. The study, which included 4,000 schools and 600,000 children, was a response to a legal requirement (Civil Rights Act 1964, sec. 402) in considering unequal educational opportunities in public schools as a result of an individual's race, religion or nationality (Coleman, 1966, p. 70).

3 Two issues arise here: first, that the black students included in the survey have a "serious educational deficit at the start of education which is obviously not the result of school" and, secondly, that "they even have a more severe deficit at the end of schooling, which is apparently at least partly the effect of education" (Coleman, 1966, p. 73).

4 These - albeit small - differences in learning between schools were attributed to the social environment provided by each school, that is to say, the nature of the educational level and aspirations of non-black children and the education of teachers in schools (ibid., pp. 73-74).

5 This is why Coleman initially supported the controversial measures of school policies aimed at greater racial and socioeconomic integration of schools, as well as racially and socially mixed school classes bringing black students from families belonging to the lower stratum together with middle class white students in order to ensure stronger peer pressure to achieve better learning. 
should therefore not be uncritically generalised, have had a significant impact on school policy and have initiated a series of criticisms as well as new research - particularly in the context of the sociology of education - that has attempted to verify the methodological adequacy of Coleman's research, based on the socalled "input-output" model. At the same time, an attempt has been made to determine whether the findings of Coleman's research also apply to schools in other countries (mainly in poor and developing countries), and in subsequent time periods. ${ }^{6}$ The research examined includes two surveys carried out by Coleman and his colleagues in the 198 os that focused on a comparison between public and private schools in the United States. ${ }^{7}$ However, as some eminent interpreters have highlighted, even more important than the actual findings of Coleman's first survey of 1966 was the redefinition of equality of opportunity, the most significant aspect being the shift of emphasis from the equality of schools to the equality of students. To put it even more precisely, from equality of access to equally well-equipped schools, to equality of students' achievements in standardised tests of knowledge (Bell, 1977, p. 619). ${ }^{8}$ Such operationalisation of the idea of equal educational outcomes is certainly controversial. Nevertheless, the actual idea of equality of educational opportunity is clear: it does not matter to the student how "equal" his or her school is in comparison with others; what counts is whether at the end of schooling he or she is adequately prepared to compete with others, to obtain the desired position in society irrespective of his or her social background. At the same time, it is not important to society to "equalise schools" in a formal sense, but rather to ensure that every child - irrespective of his or her social background - enters adulthood

6 As part of the fortieth anniversary of the publication of the Coleman Report, Adam Gamoran and Danies A. Long analysed and presented the most important studies of this kind and their results in their article "Equality of Educational Opportunity: A 40-year retrospective" (Gamoran \& Daniels, 2006).

7 Coleman, Hoffer ,\& Kilgore (1982), Coleman \& Hoffer (1987). In these studies, where Coleman and his colleagues also compared the findings with regard to the (non)impact of schools on the educational achievement of pupils from the first survey of 1966, the authors came to two important conclusions: first, that private secondary schools have a positive impact on students' learning achievements (the learning achievements of pupils are higher than in public schools), and, secondly, that learning achievements - if they are judged according to the socioeconomic status of pupils - are more fairly distributed in Catholic and other private schools than in public schools. One consequence of these findings was political support from conservatives for the neoliberal idea of the right of parents to freely choose schools, and the related request for the introduction of school vouchers.

8 Later, in 1975, in his article "Equal Educational Opportunity: A Definition", Coleman denied the usefulness of the distinction between the two perceptions of equal educational opportunities for the purpose of conducting education policies (Karabel \&. Halsey, 1977, p. 21). Nevertheless, the interpretation of equality of educational opportunity as equality of outcomes had an impact on education policy. This is materialised in the "No Child Left Behind Act" from 2001, which planned and expected from schools that, within a period of 12 years, all pupils, irrespective of their social origin, would successfully pass the national examination of knowledge. 
as well prepared as possible, in order to be granted the opportunity for full participation. Consequently, according to Coleman, a school is successful only if there is a reduction in the degree to which the child's access to opportunities is dependent on his or her social origin. Therefore, equality of educational opportunities, as understood by Coleman, "does not imply only 'equal schools", but equally effective schools whose effects will outweigh any differences that exist between children of different social origin at the beginning of schooling (Coleman, 1966, p. 71). In taking this stance, Coleman actually abandoned the hitherto dominant understanding of equality of educational opportunities as equality of starting points and, according to some interpretations, replaced it with the concept of equality of educational opportunity as equality of outcome. This was clearly an important act, the consequences of which were evident both on the level of school policies as well as theory. Nevertheless, this did not provide a satisfactory answer to the question of how to understand equality of educational opportunities. The question is in fact whether equality of outcomes is really one of the two types of equality of educational opportunities. This is the case if equality of educational opportunities is understood as a generic term comprising two species of concept: equality of starting points and equality of outcome. However, equality of opportunity and equality of outcome can also be interpreted as two different types of equality. In this case, the aforementioned claim that with the definition of equality of educational opportunities as equality of outcome Coleman redefined the concept of "equality of educational opportunity" is actually incorrect, because "equality of opportunity", as Alain Renaut points out, "is not equality of outcome" (Renaut, 2007, p. 166).

However, the purpose of the present short article is neither to advance a more detailed analysis of Coleman's notion of equal educational opportunities, nor to present any of the other more extensive and comprehensive conceptions articulated by other authors. ${ }^{9}$ The article is instead limited to a brief analysis of some arguments that call into question the well-established and widespread interpretation of equality of educational opportunity as equality of outcome, an interpretation that the present author also used to accept uncritically. The first step in this direction is to rethink some of the problems associated with the understanding of what these conceptions of equality of educational opportunities presuppose; specifically, the idea of equal opportunities. It is assumed that equality of educational opportunities is just a specific example of equal opportunities, while, on the other hand, supporters of meritocracy remain firmly

9 There is extensive literature available on this topic. The book by the present author entitled $O$ pravičnosti izobraževanja illustrates in detail the different conceptions of equality of educational opportunities (Kodelja, 2006, pp. 29-56). 
convinced that equality of educational opportunities is a prerequisite of equal opportunities in general (Stevens \& Wood, 1992, p. 5). But what is equality of opportunity? How should it be understood?

\section{Equality of Opportunity}

These questions may seem bizarre and unnecessary - as if their answers were already known - but there are in fact several answers. This fact alone is proof that equality of opportunities - whatever this may be - is not something to be taken for granted. Problems with the understanding of what the syntagma "equality of opportunity" denotes are evident both on the linguistic and the conceptual level. On the conceptual level, there are differences in the understanding of both equality and opportunity, while, on the linguistic level, there are differences of use: either the same terms are used to denote different conceptions of equality of opportunity, or different terms are used to denote one and the same conception. Thus, for example, John Rawls, in the definition of his second principle of justice, uses the term "equality of opportunity", which has been translated into other languages using various terms: for example, into Italian as egualianza di opportunità, into French as égalité des chances, ${ }^{10}$ and into Slovene mainly as enakost možnosti (literally: equality of chances/possibilities). In all of these cases, it is a question of terms that in various languages refer to one and the same issue: to Rawls' definition of equality of opportunity. ${ }^{11}$ Sometimes, however, there are two different terms in the same language, such as égalité des opportunités and égalité des chances. In such a case, it is expected that those who prefer the use of the term égalité des opportunités instead of the generally accepted égalité des chances can justify doing so, as the use of different words to denote the same thing does not bring any benefits from the cognitive perspective; on the contrary, it often only complicates the understanding

10 Individual cases in which an author translates the English term into French as égalité des opportunités are more of an exception than a rule. The reason why, for example, Marc-Antoine Dilhac picked such an unusual translation was that for him the understanding of the word chance in the phrase égalité des chances is over determined with the idea of probability (probabilité), whereas the definition of an opportunity (chance) as a probability to achieve a goal is just one of the possible theoretical definitions of the concept of opportunity (Dilhac, 2007/1, p. 12-13).

11 Rawls' conception of equal opportunities is actually a conception of "fair equality of opportunity", which he introduced in order to correct the deficiencies of formal equality of opportunity: "To this end, fair equality of opportunity is said to require not merely that public offices and social positions be open in the formal sense, but that all should have a fair chance to attain them. To specify the idea of a fair chance we say: supposing that there is a distribution of native endowments, those who have the same level of talent and ability and the same willingness to use these gifts should have the same prospects of success regardless of their social class of origin, the class into which they are born and develop until the age of reason. In all parts of society there are to be roughly the same prospects of culture and achievement for those similarly motivated and endowed" (Rawls, 2011, p. 68). 
of the very concept to which the word refers. It is a different case altogether, however, if the terms refer to different concepts of equality of opportunity. In order to define equality of opportunity, as cited by André Comte-Sponville, it is probably necessary to use the term égalité des chances, as in his interpretation of equal opportunities it is important that the word "chances" means both "opportunities" as well as "luck", in the sense of a happy or unhappy coincidence. ${ }^{12}$ In fact, Comte-Sponville emphasises the paradoxical nature of equality of opportunity (égalité des chances), because a possibility (chance), if meant as a happy coincidence or luck (chance), is "always unequal" as soon as it is revealed (Comte-Sponville, 2004). This can be clearly seen in the case of gambling. As a matter of fact, before the publication of the outcome of a lottery or any other form of gambling, the person who wins the prize is certainly luckier than the other players. If each player won, it would cease to be a gamble. The same is true of other kinds of lucky or unfortunate coincidences, which Rawls calls the "natural lottery": natural talent. This is unevenly distributed among individuals and nobody deserves - in the moral sense - to have more talent, as it is a result of brute luck, i.e., pure coincidence. On the other hand, those who do not have this luck and are born less talented are not to be blamed for this. So why talk about equality of opportunity (luck) - as both Comte-Sponville and Renaut emphasise - if luck is by definition unequal? How can we be equal in relation to something that is by definition unequal? Their response is that what equal opportunities refers to is the fact that in a society - where people are never equally gifted, as they have not all had the same luck in the natural lottery everyone is equally entitled to use all of their talents. In this case, it is no longer about a chance, but justice (Renaut, 2007, pp. 192-193). This is very clearly emphasised by Comte-Sponville, when he says that it would be unacceptable if a child were unable to develop his or her skills and succeed in life because his or her parents were too poor or undereducated. Of course, this does not mean that he or she should be as successful as others, but that he or she could be as successful if he or she had the same capabilities and came from a different environment (Comte-Sponville, 2004). Hence it follows that, as Renaut emphasises, there is a need "to compensate, particularly in schools, for inequalities that are constantly maintained by nature, society and culture" (Renaut, 2007, p. 193). Therefore, for Renaut, equality of opportunity is necessarily a matter of justice,

12 The word itself comes from the Latin cadentia, and this from the Latin cadere, which means "to fall". In this case, it refers to the fall of the dice, and it is from here that the meanings of the word "chance" derive, such as in "a happy coincidence, luck, hope of success". However, since this word, when used in the plural, also means "possibilities, hope, prospects", the words égalité des chances include both meanings: opportunities and a lucky chance. 
or more precisely, compensatory justice (ibid., p. 193). ${ }^{13}$ In this context, equality of opportunity is to be understood, which Comte-Sponville defines as "a right to not depend solely on luck or lack of luck". This right is nothing other than "an equal right of everyone to prove themselves, to make use of their talents and to overcome - at least partially - their weaknesses". In other words, "it is one's right not to remain a prisoner of one's origin, one's environment, one's status", i.e., "the right to succeed as far as we can and as far as we deserve". In this sense, equal opportunities are a right, the essence of which is to protect everyone's future, "as far as possible from the injustices of the past" (Comte-Sponville, 2004). So understood, equality of opportunity is therefore not a matter of luck, but of justice; not just any justice, but compensatory justice, which corrects the wrongs that have occurred to someone in the past (Renaut, 2007, p. 194).

One of the best-known ways to correct such injustices is the implementation of so-called policies of positive discrimination or affirmative action. ${ }^{14}$ This is one way to - at least to a certain extent - "compensate or repair the inequalities that are the result of the natural or the social lottery and offer equal opportunities to everyone so that their lives will not depend solely on luck or bad luck" (Renaut, 2007, p. 194). Equality of opportunity is therefore not a matter of luck but a matter of compensatory justice, which establishes equality in such a way as to eliminate inequalities caused by fortunate or unfortunate coincidences (ibid.). Based on these considerations, we can see that equality of opportunity (chances), as interpreted by Comte-Sponville, does not mean equal luck in the race to achieve a specific result, but equal opportunities in the sense of an equal probability of the specific result being achieved. It is about the

13 In advancing the idea of compensatory or restorative justice, Renault takes as his starting point Aristotle's distinction between distributive and countervailing justice. In the case of countervailing justice, it is essential that acting voluntarily or involuntarily in mutual relations comes to the forefront, when "one side does injustice, the other suffers, one party is doing damage and the other is being damaged" (Aristoteles, 1964, pp. 1131a-1132b). In such cases, the judge must re-establish the equality that an unjust act has upset by unjustly creating inequality (Renaut, 2007, p. 117).

14 Sometimes the two terms are used as synonyms and sometimes as terms that refer to a variety of education policies, as well as to employment, health and social care. Those who do not use them as synonyms emphasise a number of conceptual differences between the two types of policies. Some of them see the basic difference between a policy of positive discrimination and a policy of positive or affirmative action as residing in the fact that the objects of the former are people from poor backgrounds, regardless of their racial, ethnic or religious affiliation; in contrast, the object of the latter are individuals as members of specific social groups or minorities (racial, ethnic, religious). In the context of education policies, the multifaceted term "positive discrimination" is used primarily to indicate two similar yet distinct policies: positive action (the removal of barriers, which puts disadvantaged minorities in an equal position compared to the majority), and compensatory education (an increase in the education of deprivileged members of minorities and improvement in the quality of education offered by schools in socially deprivileged environments). Some authors believe that, despite their differences, these two policies are both policies of "preferential treatment", which discriminate in order to eliminate unfair differences and to re-establish equal opportunities for all. 
same understanding of equal opportunities as in the gambling mentioned above, where all players placing the same bet have an equal opportunity "to win: all are equal before the results appear. The probability calculus states this. The rules of the game guarantee this. Equal opportunities cannot depend on luck. That is to say, it depends on us to be predetermined, organised and verified, i.e., 'institutionalised'. It does not depend on luck, but on justice. Not on nature, but on society. Not on a happy coincidence, but on policies and laws. It is only one of the various forms of equality" (Comte-Sponville, 2004).

In this respect, the equality referred to in equality of opportunity would be in the same position as equality in the generic concept, as in other forms of equality, such as equality before the law or the equality of rights (Bobbio, 1995, pp. 13-30). This means that equality of opportunity does not differ from other forms of equality in response to the question "Equality between whom?", as in all of these cases there is equality between human beings. ${ }^{15}$ With regard to the question "Equality of what?", however, the answer is, of course, equality of opportunities. But equality of opportunity in relation to what? Usually it means equality of opportunity in education, employment, health care and other important public goods, and - as we have seen - in the development of personal skills and talents. The important thing, on the one hand, as indicated by Peter Westen, is that each of these opportunities is similar to others insofar as it reflects the specific relationship between the subjects to which opportunities belong, the objectives towards which the opportunities are oriented, and the obstacles that prevent the subjects from achieving these objectives. On the other hand, each of these opportunities differs from other opportunities in that it represents a "relationship between particular subjects, particular obstacles and particular objectives" (Westen, 1990, p. 171).

The key to assessing the correctness or incorrectness of the thesis that Coleman has redefined the concept of "equality of educational opportunity" is Westen's explanation of a subject's opportunity to achieve a particular objective. This opportunity is not a guarantee that the subject will achieve the goal, if he

15 This idea of equality between people, which is expressed by the maxim "All human beings are (born) equal" is present in Western political thought from the Stoics onwards, and is found in early Christianity, the Reformation, Rousseau and the utopian socialists, as well as in the various declarations on Human Rights (ibid., pp. 16-19). One of the central contemporary interpretations of this idea can be found in Dworkin. Its essence can briefly be presented with the idea that the basic moral premise of our time is that every person is of equal moral value and equal dignity, and should therefore be treated with the same respect and have equal rights (Dworkin, 1973, p. 532). Similar views can be found in several other well-known political theories (Nozick, Rawls, Singer, Nielsen), whose authors - despite a number of differences - share the common notion that every person has intrinsic value and that this value is equal. What, in Dworkin's opinion, distinguishes most modern egalitarian theories from older conceptions of natural law is that the justification of equality of people has no reference to God or any other metaphysical entity (Pojman, 1997, p. 282). 
chooses to pursue it. An opportunity is therefore not the same as a guarantee; it cannot be, because an opportunity does not imply "the absence of all obstacles between a given subject and a given objective" (Westen, 1997, pp. 24-25). Therefore, an opportunity is less than a guarantee, but at the same time - as we have seen - more than mere luck or a lucky coincidence. Hence, it follows that equality of opportunity is not and cannot be the same as equality of outcomes. This is yet another argument in favour of the initially introduced thesis set to the incorrect interpretation, according to which Coleman would have redefined the concept of "equality of educational opportunities" with the definition of equality of educational opportunity as equality of results.

The same conclusion can also be reached via a different route. Let us assume that we proceed from equality of opportunity as a principle. This principle, which is one of the foundations of a social democratic state - just as the principle of equality before the law is the foundation of a liberal state - is in essence nothing more than the application of the classical rules of fairness (equals must be treated equally and unequals differently) in the case where more than one person is competing to achieve the same objective, which can only be achieved by one or just a few of the competitors, and certainly not by all of them, as the objective they want to achieve is a limited quantity of goods, such as, winning a contest, gaining admission to a prestigious university, securing a good job, obtaining a scholarship, etc. Hence we can see that this way of perceiving equality of opportunity, as quoted by Norberto Bobbio, is not and cannot be equality of outcome. It is therefore logical that equality of opportunity is equated with equality of starting points (Bobbio, 1995, pp. 24-25).

\section{Equality of Opportunity and Equality of Outcome}

Equality of starting points is often associated with equal accessibility, but there is an important difference between the two. Equal access was derived from the principle of equality before the law. ${ }^{16}$ It was therefore initially conceived as equal access to all public services on the basis of individual merit one's abilities and virtues - and not on the basis of birth and inherited privileges. In this case, we can see that equal opportunities were understood as equality of access, and are thus similar to that which is characteristic today of the liberal

16 The principle of equality before the law has its origins in both the concept of "isonomia", which is the result of ancient Greek political thought as well as of the Enlightenment ideas of freedom and equality that inspired the French Revolution. The impact of these ideas can also be seen in the sixth article of the Declaration of the Rights of Man and of the Citizen of 1789, which - inter alia reads as follows: "All citizens, being equal in the eyes of the law, are equally eligible to all dignities and to all public positions and occupations, according to their abilities, and without distinction except that of their virtues and talents." 
notion of equal opportunities (Sartori, 1996, p. 181). However, equality of access to something for all on the basis of merit is one thing, but ensuring a level playing field that gives everyone equal initial opportunities is another altogether. Equality of access requires a form of access (the right procedures, modalities), the same starting point as well as material conditions and circumstances. Equal starting points also presuppose the prohibition of discrimination, etc. (Sartori, 1996, pp. 181-182). If we want to put individuals who are different by nature in the same starting position, then it is necessary to favour the disadvantaged or disadvantage the advantaged. This means to artificially create differences and discrimination that previously did not exist. In this way, inequality becomes a means of achieving equality, as it corrects prior inequality: the new equality is therefore the result of levelling two inequalities (Bobbio, 1995, p. 26).

This equality is not, however, equality of outcome; it is not equality in the sense that all individuals achieve the same success, that everyone can enrol in a prestigious university, obtain a well-paid job, etc. On the contrary, it is equality of opportunity that is to be understood in the sense that everyone should have an equal opportunity to become the best, and only the best obtain the social goods - because they are limited - not everyone. But what does it mean that everyone should have an equal opportunity to become the best? According to one interpretation, everyone must start from the same starting position, while, on the other hand, everyone must have access to the same amount of resources. ${ }^{17}$ In no case is there merely formal equality, requiring that everyone is subject to the same rules. That this is the case here stems from the different interpretations of equality of opportunity. Mark Cavanagh emphasises something else that often remains overlooked, as we take it for granted, i.e., that equality of opportunity is the objective of education policies and other policies because it is one of the forms of equality that has been most appreciated in Western societies, along with freedom. However, in the aforementioned interpretations of equality of opportunities - such as equality of starting points and equality of resources - the focus is not on equality as a specific value. In both cases, the starting point in the argument in favour of equal opportunities lies in a belief in competition, while equality is apparent from the very idea of competition itself. In both cases, this reasoning is based on an analogy with a race. In the first case, equality is conceived in the sense that all of the runners start the race from the same starting position, whereas, in the second case, each runner starts the race

17 The weak side of the argument regarding the equality of resources lies in the fact that the same amount of money spent on education of individuals with a different level of giftedness does not give the less capable equal opportunities compared to the opportunities that those who are more capable have at their disposal. At the same time, investing more money in the education of those who are less capable cannot lead to the same results in education. 
with the same equipment. This race metaphor is very popular in the treatment of equal opportunities, as many people think of life in a similar way. ${ }^{18}$ There are two main reasons why people see the process of education or seeking employment as a race. These reasons correspond, as Cavanagh has shown, to two concepts of meritocracy. The first assumes that a competition is the only way for us to successfully recognise that someone deserves his or her success. From here, it is only a short step to the idea that everyone should start a race as an equal. If not, it looks like the winner does not deserve his or her success. The other concept of meritocracy does not see competition as a means of enabling people to deserve their own success, but as a way of identifying an individual's natural talents. In this case, the focus is on the fact that the result of the competition is morally important in itself, but only insofar as it enables us to distinguish between those who are talented and those who are not. But even in this case, initial equality, or ensuring that the competitors originate from the same environment, is the only way to recognise their natural talents. However, neither of these two ways of understanding the race metaphor includes any reference to equality as a particular value. In neither the first nor the second case does the argument begin with a reference to equality; on the contrary, it starts with a reference to competition, while equality is taken into account only as a means to an end, i.e., as a way to recognise an individual's potentials or to ensure that winners get what they deserve. Furthermore, this goal is antiegalitarian, as it does not emphasise the equality between people, but rather promotes and recognises quite the opposite: the differences between them. Such a conception of equality of opportunity differs from one that emphasises that people must have more than a mere possibility of applying for a job in a meritocratic competition: they should be offered some sort of assistance prior to the competition itself. However, this support must be given because the competitors themselves benefit from it, and not the effectiveness of competition (Cavanagh, 2003, pp. 85-86).

Hence, it can be seen, as Onora O'Neill also emphasises, that for a society that recognises the principle of equality of opportunity, equal results are not typical: the same income, the same education and the same standard of living. Equality of opportunity, at least when it comes to its formal or liberal understanding, does not bring about equal success and equal status, but only fairness of the rules that regulate efforts to obtain such goods. This is equality of opportunity in a society in which there are winners and losers, and where it looks like the winners have earned their success and the losers their defeat, as both have

18 Such a conception of equality of opportunity and the use of this metaphor was opposed by Robert Nozick with the simple but convincing argument that life is not a race (Nozick, 1974, pp. 235-238). 
had an equal chance to win (O'Neill, 1977, p. 180). According to advocates of the formal or liberal conception of equality of opportunity, members of a society can be extremely unequal in their achievements, e.g., in education and employment. However, this inequality is justified only if it is a consequence of differences in the ability, will and desires of those who, in the process of education and seeking employment, have undergone a selection procedure. If these procedures are just, and if they are fair and impartial, there is nothing to complain about (ibid., p. 180). In this context, equality of opportunity is unambiguously perceived as being contrary to equality of results. Equality of opportunity is addressed here from the perspective of justice. Although justice is often defined as equality, inequality is not always unjust. Inequality is perceived as fair when it is the result of an individual's capacity, individual merit and the effort involved. This is why equality of opportunity goes beyond the equality of rights that belong to all people irrespective of their social or ethnic origin, gender, material status, place of birth, creed or any other important characteristic, such as a disability, as it favours people who are subject to discrimination, so that they are guaranteed fair and equitable treatment. This means that the differences related to the individual's origin and the environment need to be eliminated. In short, the liberal conception of equality of opportunity is typically associated either with equality of starting points or resources, and not with equality of outcome.

However, there is - or should be - a different conception of equality of opportunity, which Onora O’Neill labels as egalitarian: the society - as seen from an egalitarian position - that can be interpreted as one in which the level of success of the main social groups is the same. Such a conception of equality of opportunities requires that each under-representation of certain groups in the fields of education, employment, etc., may be the result of the mere freedom of choice of the members of these groups. According to the egalitarian understanding, equality of opportunity is achieved when the level of success of certain social groups that differ according to gender, ethnicity, etc. is equalised. Significant differences between the success of the most successful and the least successful individuals within the same social groups are not important if there are similar differences in other social groups as well. Nor is it required that all individuals have an equal opportunity for a particular kind of success. The egalitarian conception of equality of opportunity aims for something different: to bridge the gap between social groups (ibid., pp. 181-183). The achievement of this objective - primarily in the United States - is the aim of the aforementioned policies of positive discrimination or affirmative action, "which have often assumed the form of quota policies" (Renaut, 2007, p. 15). These policies, which promote the idea of collective rights, have been - and still are - the 
subject of numerous controversies, mainly because, according to some authors, they call into question the highest values of modern democratic societies, i.e., "individual rights" (ibid., p. 15 ). ${ }^{19}$ Since it is each individual who - according to the usual notion of equality of opportunities - should have the same opportunities as everyone else falling into the same category, it is clear that the egalitarian conception of equality of opportunity is not - at least regarding individuals the same as equality of outcome.

\section{Conclusion}

If, after this brief and rudimentary analysis, we return to the initial interpretation, according to which Coleman, with his definition of equality of educational opportunities as equality of outcome, redefined the concept of "equality of educational opportunity", we can see that this interpretation is incorrect. It is incorrect because equality of outcomes is not one of the genres of equal opportunities; it is a special kind of equality. Consequently, Coleman's redefinition of the concept of equality of educational opportunity - or the concept attributed to him - is not and cannot be a redefinition of this notion. It is a redefinition of something else: the objective of education policy. Instead of equalising schools, the objective is to equalise the educational achievements of children in these schools. The condition for this is that the educational opportunities of these children should be as equal as possible. However, this can not be achieved by ensuring an equal level of resources for individuals or social groups, as equality of resources is contrary to the aim: equal results. At least approximately equal educational outcomes can only be achieved if more educational resources are devoted to the less talented and those from a socially and culturally impoverished background. Such a redistribution of educational resources presents a major political problem, which the introduction of compensatory programmes attempted, more or less successfully, to solve. However, even if we ensured almost equal educational achievements, individual choices would have only a minor role in the education system (O'Neill, 1976, p. 287).

As Onora O'Neill emphasises, an individual's choice is an essential element of his or her opportunity. In fact, one has a chance to do something only when one can do it - if he or she chooses to do it - or if one can do what one

19 Perhaps the most famous controversy of this kind developed in relation to the regulation of admittance to university as advocated by Ronald Dworkin. In fact, he defended the policy of affirmative action and quotas, particularly regarding entry to medicine and law, i.e., the kinds of study that function - or are the most likely to function - as an effective means of achieving desirable social goals: to increase the presence of blacks and members of other minorities in these socially strategic professions, and therefore to potentially reduce the significance of racial differences in American society (Dworkin, 1977, p. 11). 
has freely chosen to do. This being the case, if one faces an obstacle that can be overcome, one is less likely to proceed (ibid., p. 287). However, if the obstacles are insurmountable and one has no chance of proceeding no matter what one chooses, then one has no opportunity to proceed. In the case that something happens to someone irrespective of his or her choice or decision, it would be misleading to describe the individual as someone who has had the opportunity to proceed (ibid., p. 276). This interpretation of opportunities, according to O'Neill, also applies to the aforementioned compensation programmes and other measures aimed at equality of educational attainment, as these measures do not take sufficient account of the free choice of those for whom the measures are intended. Therefore, in her view, it is misleading - although this is quite often the case - to identify the objective of equality of educational outcomes or results (for different social groups) as an "interpretation of equal educational opportunities" (ibid., p. 287). Such a conclusion is correct if we accept the interpretation that an individual's freedom of choice is a necessary condition of his or her opportunities. Hence it follows that it is wrong to equate equality of educational outcome with equality of educational opportunities, as Coleman did - or as he was alleged to do.

Translated by Mitja Sardoč

\section{References}

Aristoteles (1964). Nikomahova etika. Ljubljana: Cankarjeva založba.

Bell, D. (1977). On Meritocracy and Equality. In J. Karabel \& A. H. Halsey (Eds.), Power and Ideology in Education. Oxford: Oxford University Press.

Bobbio, N. (1995). Eguaglianza e libertà. Torino: Einaudi.

Cavanagh, M. (2003). Against Equality of Opportunity. Oxford: Clarendon Press.

Coleman J. S., et al. (1966). Equality of Educational Opportunity. Washington: US Government

Printing Office.

Coleman, J. S., \& Hoffer, T. (1987). Public and Private High Schools: The Impact of Communities. New York: Basic Books.

Coleman, J. S., Hoffer, T., \& Kilgore, S. (1982). High School Achievement: Public, Catholic and Private Schools Compared. New York: Basic Books.

Coleman, J. (1975). Equal Educational Opportunity: A Definition, Oxford Review of Education, 1(1), $25-29$.

Coleman, J. (1966). Equal Schools or Equal Students?, The Public Interest, 2(4), 70-75.

Comte-Sponville, A. (2004). Égalité des chances. In: Guide républican. Paris: Delagrave.

Dilhac, M.-A. (2007). Discriminations systématiques et égalité des opportunités, Revue de 
Philosophie Économique, 1.

Dworkin, R. (1973). The Original Position, University of Chicago Law Review, 40(3), 500-533.

Dworkin, R. (1977). Why Bakke has no case, New York Review of Books, November 10, 1977.

Gamoran, A., \& Long D. A. (2006). Equality of Educational Opportunity: A 40-year retrospective,

WCER Working Paper No. 2006-9, University of Wisconsin, Wisconsin Center for Education

Research, Madison 2006. Retrieved 15. 12. 2015 from http://www.wcer.wisc.edu/publications/

workingPapers/index.php.

Karabel J., \& Halsey, A. H. (1977). Educational Research: A Review and an Interpretation. In

J. Karabel \& A. H. Halsey (Eds.), Power and Ideology in Education (pp. 1-85). Oxford: Oxford

University Press.

Kodelja, Z. (2006). O pravičnosti v izobraževanju. Ljubljana: Krtina.

Nozick, R. (1974). Anarchy, State and Utopia. New York: Basic Books.

O’Neill, O. (1976). Opportunities, Equalities and Education, Theory and Decision 7, 275-295.

O’Neill, O. (1977). How Do We Know When Opportunities Are Equal?, In M. Vetterling-Braggin,

F.A. Elliston, \& J. English (Eds.), Feminism and Philosophy (pp. 177-189). Totowa: Rowman and

Littlefield.

Pojman, L. (1997). On Equal Human Worth: A Critique of Contemporary Egalitarianism. In L. P.

Pojman \& R. Westmoreland (Eds.), Equality (pp. 282-298). Oxford: Oxford University Press.

Rawls, J. (2011). Pravičnost kot poštenost: reformulacija. Ljubljana: Krtina.

Renaut, A. (2007). Égalité et discriminations. Un essai de philosophie politique appliquée. Paris:

Seuil.

Sartori, G. (1996). Democrazia. Milano: Biblioteca Universale Rizzoli.

Stevens, E. \& G. H. Wood (1992). Justice, Ideology and Education. New York: McGraw-Hill.

Westen, P. (1997). The Concept of Equal Opportunity. In L. P. Pojman \& R. Westmoreland (Eds.),

Equality (pp. 158-166). Oxford: Oxford University Press.

Westen, P. (1990). Speaking of Equality: An Analysis of the Rhetorical Force of Equality in Moral and

Legal Discourse. Princeton: Princeton University Press.

\section{Biographical note}

Zdenko Kodelja, Ph.D., senior researcher, Head of the Centre for Philosophy of Education, Educational Research Institute, Ljubljana, Slovenia. 